\title{
THE EFFECTIVENESS OF GALLERY WALK AND SIMULATION (GALSIM) TO IMPROVE STUDENTS' ACHIEVEMENT IN FIQH LEARNING
}

\author{
ISMAIL $^{1}$, SRI ANITAH W. ${ }^{2}$, \\ SUNARDI ${ }^{3}$, DEWI ROCHSANTININGSIH ${ }^{4}$ \\ Universitas Sebelas Maret Surakarta
}

\section{Abstract}

This article presents the efforts of a teacher in enhancing students' achievement through the implementation of cooperative learning model: Gallery Walk and Simulation (GALSIM). This classroom action research aims to describe the improvement of students' achievement of Fiqh subject matter. The data was collected by observation, actions, documents, and tests. This two-cycle research used four steps i.e. planning, action, observation and reflection in each cycle. The results show that the implementation of GALSIM could improve students' activity along the learning process. Moreover, the implementation of this model could also improve students' achievement at the end of their study on Fiqh.

Tulisan ini mengetengahkan upaya guru dalam meningkatkan prestasi siswa melalui penerapan model pembelajaran kooperatif berupa Gallery Walk dan Simulation (GALSIM). Penelitian tindakan kelas ini bertujuan untuk mendeskripsikan kemajuan prestasi siswa pada pelajaran Fikih. Data penelitian terkumpul melalui pengamatan, tindakan, dokumentasi, dan tes. Penelitian dengan dua siklus ini memanfaatkan empat langkah berupa perencanaan, tindakan, pengamatan, dan refleksi dalam setiap siklusnya. Temuan riset ini menunjukkan bahwa penerapan GALSIM dapat meningkatkan keaktifan siswa selama pembelajaran. Di samping

Corresponding author; email: ${ }^{1}$ ismail@walisongo.ac.id, ${ }^{2}$ anitah_ip@uns.ac.id, 33nardi_ip@uns.ac.id, ${ }^{4}$ dewi_roch@hotmail.com.

ISSN 0852-7172 (p) 2461-064X (e)

(C) 2017 Walisongo: Jurnal Penelitian Sosial Keagamaan

http://journal.walisongo.ac.id/index.php/walisongo 
ISMAIL ET AL.

itu, penerapan model ini dapat pula meningkatkan prestasi siswa dalam mempelajari Fikih.

Keywords: fiqh; cooperative learning; students' achievement; gallery walk; simulation.

\section{Introduction}

It is suggested that a teacher shall: (1) create a meaningful, fun, creative, dynamic, and dialogical atmosphere of education; (2) have a professional commitment to improve the quality of education, and (3) provide and maintain exemplary reputation of the institution, the profession, and the position in accordance with the trust given to him (UU RI No. 20, Sistem Pendidikan Nasional 2003).

Furthermore, it is affirmed that the process of learning in educational units is implemented in interactive, inspiring, fun, and challenging ways, for motivating students to actively participate and give them enough space for innovation, creativity, and independence according to their talents, interests, and physical development or psychological aspects of them (PP RI No. 32, Perubahan Atas PP No. 19, 2005 Standar Nasional Pendidikan 2013). While the religious education teachers are professional educators with the primary task of educating, teaching, guiding, directing, training, being an example, assessing, and evaluating students (PMA RI No. 16, Pengelolaan Pendidikan Agama Pada Sekolah 2016). The important question is, "Have all teachers implemented the government regulation?"

The researcher's observation in both even and odd semesters for 2016/2017 at some madrasah (Islamic school) in Semarang shows that most of the teachers-in carrying out day-to-day pedagogical tasks i.e. planning, implementing, and evaluating Islamic Religious Education (IRE) learning i.e fiqh in madrasah 
still tend to implement a teacher-centered approach where the teacher acts as the main learning resource that relies on monotonous and less varied methods. Instead the teacher seems not cultivate student-centered approach during the learning process. They have not significantly developed the potential and creativity of the students during the IRE learning process. As a result, the active participation of the students does not appear, they become passive; just listen to the teacher, and no collaboration among students in learning, as well as the invisible spirit of learning. Moreover, the student's outcomes are also not optimal. The data obtained show that the majority of student learning outcomes are still below the minimum completeness criteria. This condition is one of the real problems of learning. If the students are psychologically not interested in the methods used, they will provide a psychological feedback that does not support the learning process. The indication is they feel cold-hearted against teachers and subjects, and even lead to indifference to the practice of their religion.

It is, then, necessary to look for alternative solutions so that the learning can be more strongly encourage students to actively learn and improve academic achievement as expected. The spirit of education reform in Indonesia calls for fundamental changes in the learning system.

If we see the attainment of fiqh learning purpose, there is an imbalance between psychomotor, affective, and cognitive. Fiqh learning that has a different characteristic to other subjects should bring the students to have a competence such as the skill of worship in performing everyday Islamic rules. The data shows that the learning assessment by teachers is dominated by cognitive assessment so that there is a minimum result of students' work regarding their worship skill. Ironically, related to the cognitive aspect, the assessment instrument used still ranges 
from level 1, 2, and 3 (remember, understand, and application) and does not move to higher cognitive aspects i.e. 4, 5, and 6 (analyze, evaluate, and create) (Anderson and Krathwohl 2001). It is found that there is no creation of Islamic climate and culture in school through everyday activities that accustom students to do worship regularly as the configuration of shaping the spiritual and social attitude of them. Whereas it is very important to keep science cohesiveness learned in class.

Such condition is one of the real problems of fiqh learning in madrasah. If psychologically, the students are not motivated with the teacher's monotonous learning methods, it affects their attention and brings on no sympathy to the teachers and the subjects, even enables the emergence of an "I don't care" habit to the implementation of Islamic tenets.

Based on those data reflection and evaluation, it is necessary to find an alternative solution so that the learning, especially on fiqh subject, can encourage the students to actively learn and can improve their achievements appropriate with their parents' hope. The spirit of educational reformation in Indonesia, with the various regulatory and laws issued by the government, requires basic changes in the learning system. Among them are how the learning is able to empower all parties, schools, teachers, and especially students.

To realize the spirit, the effort and continuous movements are necessary to develop including civilize the active learning models as an alternative model of learning especially in the Islamic learning. Active learning is a learning model based on the results of research and experiment that if applied appropriately it can improve collaboration and achievements of learners.

From the observations in class 7B of the State Islamic Secondary School (MTsN 2) Semarang City before action research, it was known that the teacher's method on fiqh subject still pre- 
dominantly using lectures and the students demonstrate attitudes that are less active and tend to be passive in the course. In order to improve the skills of collaboration and student achievement as well as to facilitate the understanding of fiqh learning materials on salat, it is necessary for the teacher to find a proper way to make the students more easily understand those materials. In relation to this study, the gallery walk and simulation methods were used as learning methods in improving student achievement in figh learning, especially in the main issues of salat. Therefore, the research problem is: can the application of cooperative learning models-i.e. gallery walk and simulation type-improve the students' achievement of MTsN 2 Semarang in fiqh subject?

Both gallery walk and simulation methods are allegedly one of the methods that can be used in IRE teaching and learning. With the use of both methods, the students will be actively involved in the learning process. The students' achievement in the matter of salat is also expected to increase. There are some researchers related to the use of those methods. One of which, the use of gallery walk dan demonstration methods could increase the students' achievement on fiqh, especially in the sub-subject of hajj in the fifth class of Islamic elementary school (MI) in Weleri (Rokhmatun 2011). The difference emerges from Rokhmatun's work and this research i.e. the first one used gallery walk and demonstration methods in MI and the second was focused on the use of gallery walk and simulation methods in Islamic junior high school/MTsN 2 Semarang.

Another research tells that the use of simulation method could increase the students' achievement in the learning of Islamic education (PAI) subject in the ninth class of SMP N Lubuk Basung (Mardiati 2015). Besides, another work shows that the use of demonstration and simulation methods could increase 
the students' understanding of the right steps of $w u d u$ (Sucipto 2017). Furthermore, a research tells that the use of simulation method could increase students' achievement and motivation in learning fiqh, especially on sub-subject of Salat Id (Sulaiwi 2011). Based on these works, the research on the use of gallery walk and simulation methods is rarely done.

It is described here that this research was conducted at the State Islamic Secondary School (MTs N 2) Semarang Central Java, Indonesia. The research was conducted in the academic year 2016/2017.

The subjects were the students of the $7 \mathrm{~B}$ class. They consist of 34 students. The focus of this research is the implementation of the combined cooperative learning models i.e. Gallery Walk and Simulation (GALSIM) in fiqh learning.

It is a classroom action research that was designed to solve problems occurred in the implementation of fiq $h$ learning in the classroom and to make improvements as well as to improve the quality of learning.

There were two cycles carried out in this action research. Each of which contains four stages: planning, action, observation, and reflection. Each stage is based on the previous cycles.

The action research cycles used is the model developed by Kemmis and Taggart, as described by Arikunto (2010). Those cycles are presented in Figure 1.

In collecting data, documentation, observation, classroom action, and tests were used. The data analysis used the mixture of qualitative and descriptive quantitative. This research was declared successful if at least $85 \%$ in the classical style reached the defined minimum completeness criteria (KKM) of learning outcomes i.e. 65, and also the overall learning activity of students during the learning process reached $80 \%$. Meanwhile, in supporting this work, there are some theoretical frameworks used. 
Figure 1

Research cycles

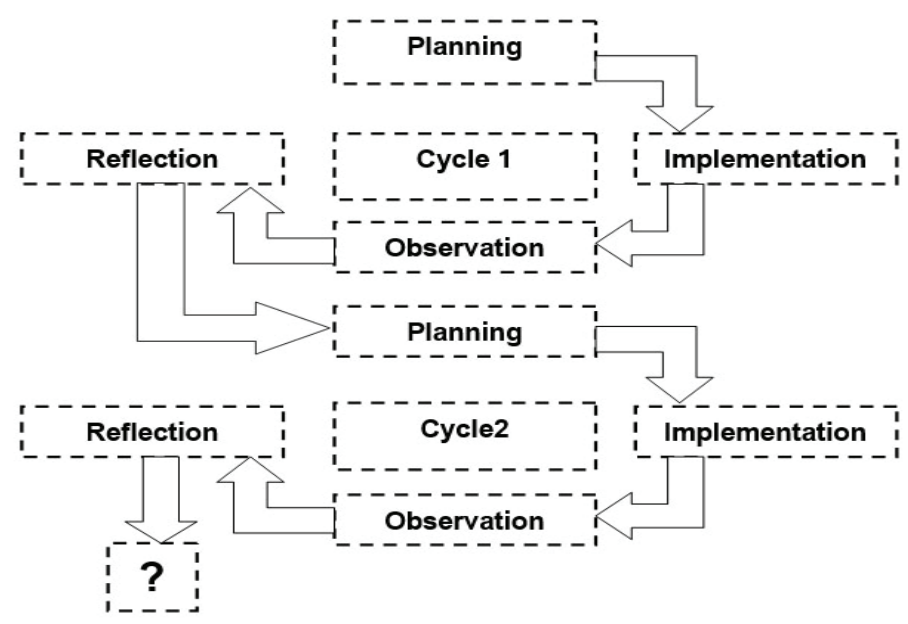

\section{Learning Activity}

\section{Definition of Activity}

The word "activity" derived from the English language. It means a condition in which things are happening or being done. Bigot defines activity as "easy or difficult nature of the act" (Bigot 1990). In this case, the activity means an activity undertaken by the students during the learning process.

According to Hamalik, students are a living organism. There are a lot of possibilities and potential of life in a growth (Hamalik 2008). Nasution states that in every student learning activities, there is an "active principle", the desire to do and work by him (self-worked). There is also an active principle of controlling his behavior. Learning needs to direct behavior toward the expected level of development. Potential life should have the opportunity to evolve towards a certain goal (Nasution 1986).

To reach optimal results in learning, it is necessary to emphasize the activities of students, physically, mentally, intellectually, 
and emotionally. In the learning process, the students' activities are nurtured and developed through questioning, critical thinking, given the opportunity to gain real experience in the practical implementation, observations, and discussion as well as there is a must for them to account for the overall results of the work assigned. In learning, according to Bruner cited by Ruseffendi, students must be active to find the principles and gain the experience to do the experiment, and the teacher encourages students to do the activities. In the learning theory, Bruner strongly suggests the student's full involvement in the learning process to achieve maximum results.

\section{Various Learning Activities}

Learning activities can be carried anywhere, in the family, the community, and the school environments. School is the dominant place to develop student learning activities. Dierdrich, as quoted by Sardiman, made a list of several kinds of student activities, namely:

1. Visual activities, includes reading, notice, demonstrations, and experiments.

2. Oral activities, such as state, ask, give something, give an opinion, and conduct interviews, discussions, and interruptions.

3. Listening activities, e.g. listening, description, conversation, music, and speech.

4. Writing activities, such as writing stories, essays, reports, questionnaires, and copying.

5. Drawing activities, such as draw, create graphs, maps, and diagrams.

6. Motor activities, for example, doing an experiment; create a construction, models of perception, playing, gardening, and farming. 
7. Mental activities, such as regarding, remembering, problem-solving, analyzing, viewing support, and making a decision.

8. Emotional activities, for example, having an interest, get bored, brave, calm, and nervous (Sardiman 1988).

Teaching and learning process is an activity that always pays attention to the development of cognitive, affective, and psychomotor that is realized in several learning activities. These three aspects are united in one individual and appear in the form of creativity. While the coaching and development of creativity mean to enable students in learning activities. In the learning process, students not only receive but are also expected to find something by their own (way).

Performing a variety of learning activities means to make learning more effective. The activities include hearing, seeing or doing other actions enables the learning experience gain better. Meeting the needs to hang out and to know the students, teachers, and others is one way to meet the social needs of students. In this case, the school is seen as an institution where the persons there can hang out and adapt to the environment, the place where the teachers can generate and create an atmosphere of cooperation, mutual assistance, and others, so it can present a better learning experience. This activity is better known as a social activity.

\section{Factors Affecting Learning Activities}

There is an argument that there are three factors affect learning activities, namely: learning stimuli factors, learning methods, and the individual factors (Soemanto 1987). The three factors are clearly outlined as follows: 
1. Learning stimuli factors. It refers to everything outside the individual that stimulates an individual to hold or act on learning reaction. Actions or learning activities due to this stimuli factor causes a push or motivation and interest in conducting learning activities.

2. Learning method factors. In the learning process, the method used by the teachers will affect students' learning.

3. Individual factors. Individual factors of students are also very influential in students' learning activities. These factors relate to things like maturity, previous experience, and state of health.

\section{Benefits of Learning Activities}

Hamalik mentions eight benefits in the use of the principle of learning activities, namely:

1. Students seek his (own) experience and direct experience.

2. Acting alone will develop all aspects of students' personal.

3. Cultivate harmonious cooperation among students, so that it can facilitate group work.

4. Students learn and work based on their own interests and abilities, so it is very useful in order to service individual differences.

5. Cultivate learning discipline, democratic, family, deliberation and consensus.

6. Maintaining and fostering co-operation between schools and communities, and the relationship between teachers and parents which is beneficial in the education of students.

7. Learning is implemented realistically and concretely, so it can develop an understanding and critical thinking as well as to avoid the occurrence of verbalism.

8. Learning becomes exist as the dynamic life in the community (Hamalik 2008). 


\section{Learning Achievement}

Slameto imposes a limit on the definition of learning. It is, according to him, an attempt of individuals to acquire new behavior changes as a whole, as a result of his own experience in interacting with the environment (Slameto 1995).

Achievement of learning is interpreted as an attained result of the learners' activities concerning with their learning (Azwar 1998). It is also defined as the results achieved by the students as a result of their learning, in the form of numbers, letters, or actions which reflect the learning outcomes achieved by each of them in a certain period (Buchori 1985). Therefore, the above three aspects should also be an indicator of academic achievement. That is, the three of which are not mutually exclusive, but integral and inseparable.

For the sake of getting a good achievement, it is possible to find a lot of difficulties since these are influenced by many factors. M. Sobri Sutikno mentions the following two factors: (a) internal factors, factors that exist in one's own self, consist of physical factors and psychological factors, and (b) external factors, factors that are outside one's own self, such as family circumstances, school, and society (Sutikno 2007).

Furthermore, academic achievement can be grouped into three aspects: cognitive, affective, and psychomotor. The first aspect relates to the new introduction or recall, comprehending, applying, analyzing, and evaluation capabilities. The second relates to the generation of interests, attitudes or emotions, and respect (compliance) of the values or norms. The third aspect refers to the nature of teaching skills or showing motion (skill). Hand skill, for example, shows the person's level of expertise in a task or set of certain tasks (Sudjana 1999). 


\section{Fiqh Learning}

Fiqh, according to the language, is understood. While according to the terms, it means a science of law (syar'iyyah amaliyah) obtained from the specific arguments (Al-Ghazy 1990). Figh subject is a part of the IRE subject in madrasah. It is considered important for students. In general, it contains the main points of Islamic law in detail and thoroughly, either arguments in the shape of aqli or naqli and there are correct practices of Islamic law (Khairuddin 2007).

Fiqh learning aims to lead learners to be able to understand the main points of Islamic law and its implementation procedures to be applied in everyday life so that they become Muslim who always obey the Islamic law kaffah (perfectly) (PMA RI No. 2, Standar Kompetensi Lulusan Dan Standar Isi Pendidikan Agama Islam Dan Bahasa Arab 2008). Fiqh learning in junior secondary school aims to equip the students in order to: (a) know and understand the main points of Islamic law in regulating the procedures for running the human relationship with God which is set in the fiqh of worship and the relationship with fellow human beings that are set in the tenets of fiqh, and (b) enforce the worship of God and social worship. The experience is expected to foster obedience in performing Islamic law, discipline and high social responsibility in his life and social (PMA RI No. 2, Standar Kompetensi Lulusan Dan Standar Isi Pendidikan Agama Islam Dan Bahasa Arab 2008).

IRE learning has different characteristics with other subjects. The approaches of IRE learning including fiqh in every aspect are developed in an integrated learning environment, including: 1. Faith, which encourages the students to develop an understanding and belief in Allah as the source of life.

2. Practice, conditioning the learners to practice and feel the results of the fiqh content in everyday life. 
3. Habituation, implementing the learning by familiarizing to perform religious ordinances, being a society and the state in accordance with fiqh subject exemplified by the scholars.

4. Rational, improving the quality of learning processes and outcomes of fiqh with an approach that enables the learner's intellectual, so that the content and the values instilled can be easily understood by reasoning.

5. Emotional, an effort to arouse the learners' feelings (emotions) in fully comprehending the implementation of worship so much impressed in the soul of the learners.

6. Functional, presenting fiqh material that provides tangible benefits for learners in everyday life in a broad sense.

7. Example, the education that locates and plays teachers and other school's components as an example, as a reflection of the individuals who practice the fiqh material (BSNP 2007).

\section{Results and Discussion}

The teaching method is one of the key principal achievements of the learning outcomes. By using appropriate and relevant teaching methods, the learning objectives can be achieved effectively. Application of teaching methods needs to pay attention to the participation of students to engage actively in the learning process. Students need to be stimulated are designed to solve problems in both individual learning and group work, so that they are trained to learn independently and find the wanted answers.

The application of the combined cooperative learning models i.e. Gallery Walk and Simulation (GALSIM) by teachers is expected to encourage students and motivate them to learn actively and eagerly to continuously reach learning achievement.

Gallery walk method is part of an existing learning model in PAIKEM-based learning model (Active, Innovative, Creative, 
Effective, and Fun) (Ismail 2008). The Gallery Walk is a learning model which the activities are followed by some groups to complete tasks together and then they exhibit the works while walking to other groups.

The simulation method is a certain person's behavior to perform a specific behavior such person intended, directing him to learn more about how the person feels to do something (N.K. 2006). So, students here practice taking a role as the person doing a particular activity. For example, in Hajj simulation, the students demonstrate as like the people who are performing Hajj.

Gallery walk and simulation method is also a learning method in which students are given full opportunity to develop their creativity. The goal of these methods is to enable the students being active in the class, whether relates to the presence, expression, and discovery of new things. Students do not become passive individuals who only listen to the teacher or simply record any information so that no impression left on them. Learning is also considered as a fun learning since it deals with the real life that exists in the daily lives of students. Study groups also support their passion to learn because there is an interaction between the advanced students to help others who do not know about the subject matter being studied.

The implementation steps of gallery walk method generally includes: (a) participants are divided into several groups, (b) each group is provided flipcharts to pour group work, (c) each group is given a lesson topic with a clear and detailed worksheet, (d) each group cooperate to discuss the topic of learning, (e) the results of group work on the flipcharts taped to the wall in sequence, (e) each group rotates to observe, appreciate, and record the work gallery of other groups, (f) one representative of each group explain the questions of other groups, $(\mathrm{g})$ correction together, and (h) clarification and inference refer to the learning objectives designed by the teacher (Ismail 2008). 
Meanwhile, the simulation method is applied with a reference to the sequence of following steps: (a) the topic determination and simulation purposes, (b) teachers provide outlines of the situation to be simulated, (c) teacher leads group organization, roles to be played, room setting, tool setting and so on, (d) the elections of the role holder, (e) teachers provide information about the role to be performed, (f) the teacher provides an opportunity to prepare himself to the group and the role holder, (g) determining location and time of the simulation implementation, (h) the implementation of simulation, (h) the evaluation and provision of feedback, and (i) retraining when needed (Hasibuan dan Moedjiono 1997).

The cooperative learning models i.e. gallery walk and simulation (GALSIM) are models that try to lay the groundwork and develop a scientific way of thinking. These approaches put students to learn more on their own (ways) and develop creativity in solving problems. Students are strongly placed on the subject of the study. The role of the teacher here is a learning mentor and facilitator. Students do their activities independently or in groups to discuss problems with the determined material.

Fiqh learning through GALSIM model links the learning materials to students' lives. As explained previously, fiqh is a subject that relates to everyday life, so in this lesson students learn with fun and are prosecuted to be active.

For the application of cooperative learning models i.e. gallery walk and simulation (GALSIM) on fiqh subjects in grade 7B the state Islamic Secondary School-34 students, an action research with 2 cycles were conducted. Cycle 1 was held for 1 meeting, and cycle 2 was 2 meetings. Pre-cycle data was necessary to determine the ability of learners before using the model.

At the pre-cycle step, the initial data-lists of students and their initial value-were collected. Their initial values were taken from the documents of the subject teachers based on students' 
daily values. The data obtained showed that the average value of the students' learning results is 63.90 and the percentage of student's activity in the pre-cycle is $61.43 \%$ and still did not meet the defined minimum completeness criteria (KKM) i.e. 65 and $65 \%$ for classical completeness.

In cycle 1 , the first meeting was presenting the learning objectives and dividing students into five groups. Heterogeneous grouping was done. Before the study started, the students were first given an overview of the application of the combined cooperative learning models i.e. gallery walk and simulation (GALSIM), then the learning was begun with the materials of salat.

Based on the evaluation results of cycle 1 , the average values of students' learning outcomes obtained 68.90 and $68.58 \%$ for classical completeness. These results demonstrate the achievement of KKM, but there were still 9 students who have not passed the KKM. Thus, the further treatment was required i.e. cycle 2 . The description can be seen in the table below:

\section{Table 1}

Comparison of total score and percentage of students' learning activity in pre-cycle and cycle 1

\begin{tabular}{ccc}
\hline Cycle Implementation & Total Points & Percentage (\%) \\
\hline Pre-cycle & 43 & 61,43 \\
\hline Cycle 1 & 48 & 68,58 \\
\hline
\end{tabular}

Table 2

Comparison of average final test in pre-cycle and cycle 1

\begin{tabular}{cc}
\hline Cycle Implementation & Average \\
\hline Pre-cycle & 63,90 \\
\hline Cycle 1 & 68,90 \\
\hline
\end{tabular}


In cycle 2, there was a discussion at the first meeting i.e. hajj and umrah material. Based on the evaluation result of cycle 2, the average value of the students' learning outcomes reached 74.76 and for students' activity score is $78.58 \%$. Then the result of the action of the pre-cycle, cycle 1 , and cycle 2 can be summarized as follows:

1. There was an increase in learners' activity from pre-cycle, cycle 1 and cycle 2 which can be seen in the following table:

Table 3

Comparison of total score and percentage of students' learning activity in pre-cycle, cycle 1, and cycle 2

\begin{tabular}{ccc}
\hline Cycle Implementation & Total Points & Percentage (\%) \\
\hline Pre-Cycle & 43 & 61,43 \\
\hline Cycle 1 & 48 & 68,58 \\
\hline Cycle 2 & 55 & 78,58 \\
\hline
\end{tabular}

2. Final test results also showed an increase from pre-cycle, cycle 1 , and cycle 2 which can be seen in the following table:

Table 4

Comparison of average final test in pre-cycle, cycle 1 , and cycle 2

\begin{tabular}{cc}
\hline Cycle Implementation & Average \\
\hline Pre-cycle & 63,90 \\
\hline Cycle 1 & 68,90 \\
\hline Cycle 2 & 74,76 \\
\hline
\end{tabular}

Based on the facts above, it is revealed that the application of gallery walk and simulation method in this study had a positive impact on the learners' learning activities, especially to reduce boredom and as a variety of learning. From the three stages of the application of both methods, it is also apparent that there is an increase in student achievement toward better after the implementation when compared to the previous. 


\section{Conclusion}

From the previous exposure, it can be concluded that the application of cooperative learning models i.e. gallery walk and simulation (GALSIM) in this study had a positive impact on learners' learning activities, primarily reduce boredom and as a variety of learning. There were some students of grade $7 \mathrm{~B}$ at the State Islamic Secondary School (MTsN 2) Semarang who previously had a low learning outcome rose to be higher in their participation of learning. It can be seen from the percentage of acquisition score through observations of student learning activities with indicators of readiness and activity in the learning process.

\section{Graphic 1}

The increase of learner's activity and test results

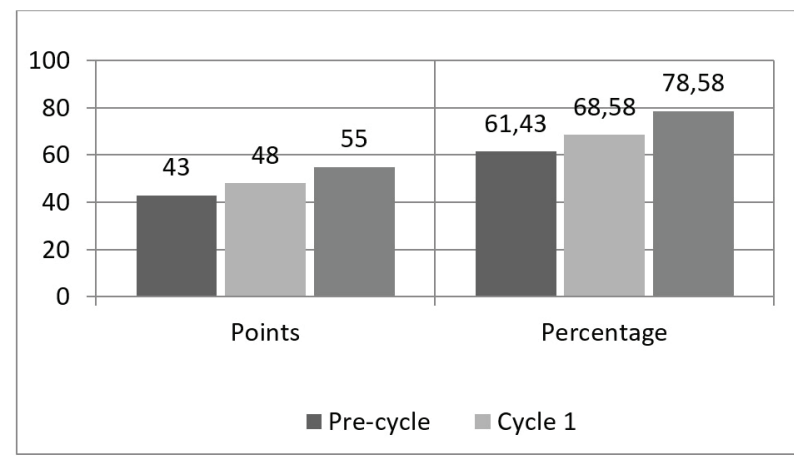

The percentage of increase in activity learning from pre-cycle, cycle 1 to cycle 2 was increased from $61.43 \%$ to $68.58 \%$ and $78.58 \%$ and it reached over the defined average i.e. $65 \%$. While the increase in the ultimate test from pre-cycle, cycle 1 , and to cycle 2 can be seen from the average value in each cycle i.e. 63.90 and increased to 68.90 and 74.76. These increases are resumed in the Graphic 1. From these two cycles of the action, it was found that there was an increase in activity and learning 
outcomes through the application of a combination of cooperative learning models (gallery walk and simulation) when compared with the previous.

\section{Bibliography}

Al-Ghazy, Syekh Muhammad Qasim. 1990. Syarah Fathul Qarib. Semarang: Pustaka Al-Alawiyah.

Anderson, Lorin W., and David R. Krathwohl. 2001. A Taxonomy for Learning, Teaching and Assessing: A Revision of Bloom's Taxonomy of Educational Objectives. White Plains, NY: Addison Wesley Longman.

Arikunto, Suharsimi. 2010. Prosedur Penelitian: Suatu Pendekatan Praktik. Jakarta: Rineka Cipta.

Azwar, Saefuddin. 1998. Tes Prestasi Fungsi Pengembangan Pengukuran Prestasi Belajar. Yogyakarta: Pustaka Pelajar.

Bigot, Icy. 1990. Leerboek Der Psychologie. Bandung: Jenmars.

BSNP. 2007. Kurikulum Tingkat Satuan Pendidikan Khusus Madrasah Tsanawiyah (MTs). Jakarta: PT Binatama Raya.

Buchori, M. 1985. “Teknik-Teknik Evaluasi Pendidikan .” Bandung Jemmars.

Hamalik, Umar. 2008. Kurikulum Dan Pembelajaran. Jakarta: Bumi Aksara.

Ismail. 2008. Strategi Pembelajaran Agama Islam Berbasis PAIKEM. Semarang: RaSAIL Media Group.

Khairuddin. 2007. Kurikulum Tingkat Satuan Pendidikan KTSP Konsep Dan Implementasi Di Madrasah. Yogyakarta: Pilar Media.

Mardiati. 2015. "Penggunaan Metode Simulasi Untu Mening- 
katkan Hasil Pembelajaran Pendidikan Agama Islam Di Kelas IX B SMP N Lubuk Basung.” Jurnal Pelangi 7 (2). doi:10.22202/jp.2015.v7i2.199.

N.K., Roestiyah. 2006. Strategi Belajar Mengajar. Jakarta: Rineka Cipta.

Nasution, S. 1986. Didaktik Asas-Asas Mengajar. Bandung: Jenmars.

PMA RI No. 16, Pengelolaan Pendidikan Agama Pada Sekolah. 2016. Indonesia.

PMA RI No. 2, Standar Kompetensi Lulusan Dan Standar Isi Pendidikan Agama Islam Dan Bahasa Arab. 2008. Indonesia.

PP RI No. 32, Perubahan Atas PP No. 19, 2005 Standar Nasional Pendidikan. 2013. Indonesia.

Rokhmatun, Siti. 2011. "Upaya Meningkatkan Prestasi Belajar Fikih Materi Pokok Haji Melalui Penerapan Metode Gallery Walk Dan Demonstrasi Di Bagi Siswa Kelas Tahun Pelajaran 2010/2011.” IAIN Walisongo.

Sardiman, A M. 1988. Interaksi Dan Motivasi Belajar Mengajar Pedoman Bagi Guru. Jakarta: Rajawali.

Slameto. 1995. Belajar Dan Faktor-Faktor Yang Mempengarubinya. Jakarta: Rineka Cipta.

Soemanto, Wasty. 1987. Psikologi Pendidikan. Jakarta: Bina Aksara.

Sucipto. 2017. "Peningkatan Pemahaman Cara Berwudhu Melalui Penerapan Metode Demonstrasi Dan Simulasi Di Sekolah Dasar." Brilliant: Jurnal Riset Dan Konseptual, $25-31$. 
THE EFFECTIVENESS OF GALLERY WALK ...

Sudjana, Nana. 1999. Penelitian Hasil Proses Belajar Mengajar. Bandung: Rosdakarya.

Sulaiwi. 2011. "Peningkatan Motivasi Belajar Dan Hasil Belajar Materi Pokok Salat Id Melalui Metode Simulasi Pada Siswa Kelas Tanjungsari Tlogowungu Pati Tahun Ajaran 2010/2011.” IAIN Walisongo.

Sutikno, M Sobri. 2007. Rahasia Sukses Belajar Dan Mendidik Anak. Mataram: NTP Press.

UU RI No. 20, Sistem Pendidikan Nasional. 2003. Indonesia. 
This page intentionally left blank 